\title{
Grazing Density Effects on Cover, Species Composition, and Nitrogen Fixation of Biological Soil Crust in an Inner Mongolia Steppe
}

\author{
Huajie Liu, ${ }^{1}$ Xingguo Han, ${ }^{2}$ Linghao Li, Jianhui Huang, ${ }^{2}$ Hongsheng Liu, ${ }^{3}$ and Xin $\mathrm{Li}^{4}$ \\ Authors are ${ }^{1}$ Postdoctoral Associate, ${ }^{2}$ Professors, ${ }^{3}$ Assistant Professor, and ${ }^{4}$ Research Technician, State Key Laboratory of Vegetation and Environmental \\ Change, Institute of Botany, Chinese Academy of Sciences, 20 Nanxincun, Beijing 100093, People's Republic of China.
}

\begin{abstract}
Biological soil crusts (BSCs) are important in many arid and semiarid ecosystems for their abilities to fix atmospheric nitrogen (N) and stabilize surface soil. Grazing disturbance has a profound influence on abundance, species composition, and ecological functioning of BSCs. To elucidate the effects of grazing on BSCs in Inner Mongolia grasslands, an investigation was conducted in a typical steppe that had previously been subjected to long-term grazing with six grazing densities (control: 0 sheep $\cdot \mathrm{ha}^{-1}$, very light: 4 sheep $\cdot \mathrm{ha}^{-1}$, light: 8 sheep $\cdot \mathrm{ha}^{-1}$, medium: 12 sheep $\cdot \mathrm{ha}^{-1}$, heavy: 16 sheep $\cdot \mathrm{ha}^{-1}$, and very heavy: 20 sheep $\cdot \mathrm{ha}^{-1}$ ). Cover, species composition, potential $\mathrm{N}$-fixing activity, and potential $\mathrm{N}$ input of BSC indicate that long-term grazing significantly reduced the importance of BSC in N input and soil stabilization. Such reductions were highly related to grazing density. Very light grazing had no significant effect on the role of BSC in soil stabilization, but resulted in a $13.3 \%$ reduction in BSC N input potential. Heavy and very heavy grazing led to a decrease of potential $\mathrm{N}$ input by one order of magnitude, and a decline of BSC function via a shift from high coverage of an attached group-dominated BSC community to a low coverage of a vagrant group-dominated community. Constraining grazing level to a very light density —and to a lesser extent, a light grazing density-is likely a preferred practice for conserving BSC and the ecological services it provides in N fixation and soil stabilization.
\end{abstract}

\section{Resumen}

Las costras biológicas del suelo (CBSs) son muy importantes en varios de los ecosistemas áridos y semiáridos por su habilidad de fijar el nitrógeno (N2) atmosférico y estabilizar la superficie de los suelos. El disturbio por el pastoreo tiene una profunda influencia en la abundancia, composición de especies y el funcionamiento ecológico de las CBSs. Para clarificar el efecto del pastoreo en CBS en los pastizales de Mongolia, esta investigación se condujo en un pastizal típico que previamente había sido sujeto a pastoreo por largo tiempo con seis densidades de pastoreo (control: 0 ovejas $\cdot \mathrm{ha}^{-1}$, pastoreo muy ligero: 4 ovejas $\cdot \mathrm{ha}^{-1}$, pastoreo ligero 8 ovejas $\cdot \mathrm{ha}^{-1}$, pastoreo moderado: 12 ovejas $\cdot \mathrm{ha}^{-1}$, pastoreo pesado 16 ovejas $\cdot \mathrm{ha}^{-1}$, y pastoreo muy pesado 20 ovejas $\cdot \mathrm{ha}^{-1}$ ). La cobertura, la composición de las especies, el potencial de la actividad de fijación del $\mathrm{N}$ y el potencial de la contribución del $\mathrm{N}$ de las CBS indica que el pastoreo a largo plazo reduce significativamente la importancia de las CBS en la contribución del $\mathrm{N}$ y la estabilización del suelo. Tales reducciones fueron altamente relacionadas con la densidad del pastoreo. El pastoreo muy ligero no tiene ningún efecto significativo en el papel de las CBS en la estabilización del suelo, pero resulta en una reducción de $13.3 \%$ de en la contribución potencial del N de las CBS. El pastoreo pesado y muy pesado tiende a disminuir el potencial de la contribución del $\mathrm{N}$ por una gran magnitud y disminuye la función de las CBS a través de un cambio de gran cubierta? de un grupo adherido dominado por la comunidad de CBS a un grupo de una comunidad de baja cobertura de de un grupo no estable. La limitación del pastoreo a un nivel muy ligero y a un grado de un pastoreo muy ligero es posiblemente una práctica preferida para la conservación de las CBS así como los servicios ecológicos que este proporciona en la fijación del $\mathrm{N}$ y la estabilidad del suelo.

Key Words: acetylene reduction assay, nitrogen fixation, nitrogen input, soil stability

\section{INTRODUCTION}

Biological soil crusts (BSCs) are complex associations of cyanobacteria, eukaryotic algae, lichens, and mosses occurring as a thin layer on and just beneath the soil surface. They are common and widespread in arid and semiarid regions all over

Research was funded by National Natural Science Foundation of China Grant 30521002 from an Innovative Research Group Project of National Natural Science Foundation of China and the State Key Basic Research Development Program of China (2007CB106800).

Correspondence: Xingguo Han, State Key Laboratory of Vegetation and Environmental Change, Institute of Botany, Chinese Academy of Sciences, 20 Nanxincun, Beijing, 100093, China. Email: xghan@ibcas.ac.cn

Manuscript received 29 July 2008; manuscript accepted 5 April 2009. the world, and provide critical ecosystem functions (West 1990; Evans and Johansen 1999). BSCs can stabilize soil against both water and wind erosion (Belnap and Gillette 1998; Malam Issa et al. 2001; Langston and McKenna Neuman 2005; Barger et al. 2006); fertilize soil by nitrogen (N) fixation (Harper and Belnap 2001; López-Hernández et al. 2006); and enhance seed germination (Hawkes 2004; Rivera-Aguilar et al. 2005), seedling establishment (Rivera-Aguilar et al. 2005), and survival and biomass production of vascular plants (Pendleton et al. 2003).

The Inner Mongolia steppe represents the largest contiguous grassland ecosystem in China. Rapid degradation and desertification have taken place in these grasslands, primarily caused by overgrazing that reduced vascular plant cover, accelerated 
soil loss, and decreased soil nutrient level (Li et al. 2000). When the steppe was released from grazing, the reoccurrence of BSCs was commonly seen and regarded as an indicator of improving grassland health (Li et al. 2001). Previous studies have shown that grazing disturbance has profound influences on coverage, species composition, and N fixation of BSCs (Warren and Eldridge 2003; Thomas and Dougill 2006). Because BSCs can be the dominant source of $\mathrm{N}$ input and an important soil stabilizer in many arid and semiarid ecosystems (Evans and Ehleringer 1993; Evans and Johansen 1999; Langston and McKenna Neuman 2005; Barger et al. 2006), the impacts of grazing on role of BSCs in ecosystem $\mathrm{N}$ input and soil stabilization can be sizeable (Warren and Eldridge 2003). Such impacts may further accelerate degradation and desertification in these ecosystems.

Livestock grazing in Inner Mongolia grassland ecosystems has traditionally focused on vascular plant-grazing and soilgrazing relationships, but little work has been done on the impacts of grazing on BSCs ( $\mathrm{Li}$ et al. 2000). The lack of such information limits our understanding of the grazing effect on grassland ecosystems, which will affect our ability to manage these ecosystems and to restore these degraded Chinese grasslands.

The objectives of this study were to examine the effects of grazing on BSCs by quantifying coverage, species composition, potential $\mathrm{N}$-fixing activity $\left(\mathrm{N}_{\mathrm{A}}\right)$ and potential $\mathrm{N}$ input of BSCs as a function of different grazing densities from a typical steppe in Inner Mongolia. We examined the impact of grazing density on 1) coverage and species composition of BSCs and 2) $\mathrm{N}_{\mathrm{A}}$ and the role of BSCs in $\mathrm{N}$ input and soil stabilization.

\section{MATERIAL AND METHODS}

\section{Site Description}

The experiment was carried out in a long-term experimental field site of the Inner Mongolia Grassland Ecosystem Research Station, which is located in the Xilin River Basin, Inner Mongolia, China (lat $43^{\circ} 38^{\prime} \mathrm{N}$, long $116^{\circ} 42^{\prime} \mathrm{E}$ ) and administered by the Institute of Botany of the Chinese Academy of Sciences. The climate is classified as a semiarid monsoon climate of moderate temperate zone, with an annual mean temperature of $0.5-1{ }^{\circ} \mathrm{C}$. Mean annual precipitation is approximately $350 \mathrm{~mm}$, with rain concentrated between June and August. The average growing season is about $150 \mathrm{~d}$. The main soil type in the study area is chestnut sandy soil with $\mathrm{pH}$ ranging 7.5-7.8. The dominant species are Artemisia frigida Willd., Cleistogenes squarrosa (Trin.) Keng, Agropyron cristatum (L.) Gaertn., and Carex duriuscula C. A. Mey.

\section{Grazing Treatment}

The grazing experiment was carried out over $16 \mathrm{yr}$ from May 1989 (Wang et al. 2001) to October 2004. The design was six grazing densities (control: 0 sheep $\cdot \mathrm{ha}^{-1}$, very light: 4 sheep $\cdot \mathrm{ha}^{-1}$, light: 8 sheep $\cdot \mathrm{ha}^{-1}$, medium: 12 sheep $\cdot \mathrm{ha}^{-1}$, heavy: 16 sheep $\cdot \mathrm{ha}^{-1}$, and very heavy: 20 sheep $\cdot \mathrm{ha}^{-1}$ ) with three 1 -ha replicates per treatment. Sheep grazed rotationally three times per year, with $15 \mathrm{~d}$ grazing at an interval of $30 \mathrm{~d}$ from May to October.

\section{Biological Soil Crust Components}

Five dominating components of BSC were recognized in the study site: 1) a cyanolichen, Collema tenax (Sw.) Ach. (CT); 2) mixed filamentous cyanobacteria (CY), dominated by Nostoc spp. and Scytonema spp.; 3) mosses, dominated by Bryum argenteum Hedw. and Tortula spp.; 4) a large foliose cyanobacterium, Nostoc commune Vauch. (NC); and 5) a phycolichen, Xanthoparmelia camtschadalis (Ach.) Hale (XC). According to their N-fixing capability, these components were classified into two functional groups, a non-N-fixer group (NNFG; including mosses and $\mathrm{XC}$ ) and an $\mathrm{N}$-fixer group (NFG; including CT, CY, and NC), to examine $\mathrm{N}$ fixation and $\mathrm{N}$ input responses to grazing density. They were also grouped according to their attachment to the soil: attached group (AG, including CT, CY, and mosses) and vagrant group (VG, including $\mathrm{NC}$ and $\mathrm{XC}$ ) to evaluate grazing effects on BSC ability to stabilze soil. Other occasional species, including some lichens such as Endocarpon spp., Cladonia spp., and Psora spp., and some species of Hepaticae, were assigned to NNFG and $\mathrm{AG}$.

\section{Measurements}

BSC coverage and potential $\mathrm{N}_{\mathrm{A}}$ of the three $\mathrm{N}$-fixers (CT, CY, and NC) were measured in September 2005, when vascular plant biomass reached its peak. For each combination of the three replicates by six treatments, the cover of BSC and its components was averaged over 34 randomly selected subplots with the size of $0.25 \mathrm{~m}^{2}$. A quadrat frame of $50 \times 50 \mathrm{~cm}$ subdivided into 2500 subgrids, each measuring $1 \times 1 \mathrm{~cm}$, was laid as close to the ground as possible to ensure accurate measurement of BSC cover. The cover of BSC components was recorded as the percentage of subgrids in which they occurred.

Potential $\mathrm{N}_{\mathrm{A}}$ of the three $\mathrm{N}$-fixers was determined using the acetylene reduction assay technique (Hardy et al. 1973). For each $\mathrm{N}$-fixer in a replicate, $\mathrm{N}_{\mathrm{A}}$ was averaged over five randomly collected samples. Crusts were carefully sliced off the soil surface, placed in petri dishes, and immediately wetted to field capacity. They were then placed outdoors for $24 \mathrm{~h}$ to eliminate the effects of preexisting conditions (Belnap 2002, 2003). CT and CY samples with a surface area of $10-15 \mathrm{~cm}^{2}$ and NC samples with an amount corresponding to $0.5 \mathrm{~g}$ dry weight were used. Samples were placed into $250-\mathrm{mL}$ sealed jars and completely wetted again with distilled water; then enough $\mathrm{C}_{2} \mathrm{H}_{2}$ was added to create a $10 \%(\mathrm{v} / \mathrm{v}) \mathrm{C}_{2} \mathrm{H}_{2}$ atmosphere. The jars were placed in an incubator lighted with cool white fluorescent bulbs for $8 \mathrm{~h}$ at $28^{\circ} \mathrm{C}$ to measure $\mathrm{N}_{\mathrm{A}}$. Then $200 \mathrm{~mL}$ of air in the jars was trapped in airtight airbags. The airbags were transferred to the Institute of Atmospheric Physics of the Chinese Academy of Sciences, Beijing, for ethylene concentration measurement. The ethylene concentration of air samples was measured in a Hewlett-Packard 5890 gas chromatograph using nitrogen as the carrier gas $\left(30 \mathrm{~mL} \cdot \min ^{-1}\right)$. Calibrations with ethylene standards were done at the time of observations. Results of the observed $\mathrm{N}_{\mathrm{A}}$ are reported in $\mu \mathrm{mol} \mathrm{C} \mathrm{H}_{2} \cdot \mathrm{m}^{-2} \cdot \mathrm{h}^{-1}$.

In each replicate, $\mathrm{N}$ input potentials of $\mathrm{CT}, \mathrm{CY}$, and $\mathrm{NC}$ are defined as the product of their respective coverage and $\mathrm{N}_{\mathrm{A}}$, and are summed to obtain potential $\mathrm{N}$ input of total BSC. Potential $\mathrm{N}$ input is reported as $\mu \mathrm{g} \mathrm{N} \cdot \mathrm{m}^{-2} \cdot \mathrm{h}^{-1}$. The conversion factor 


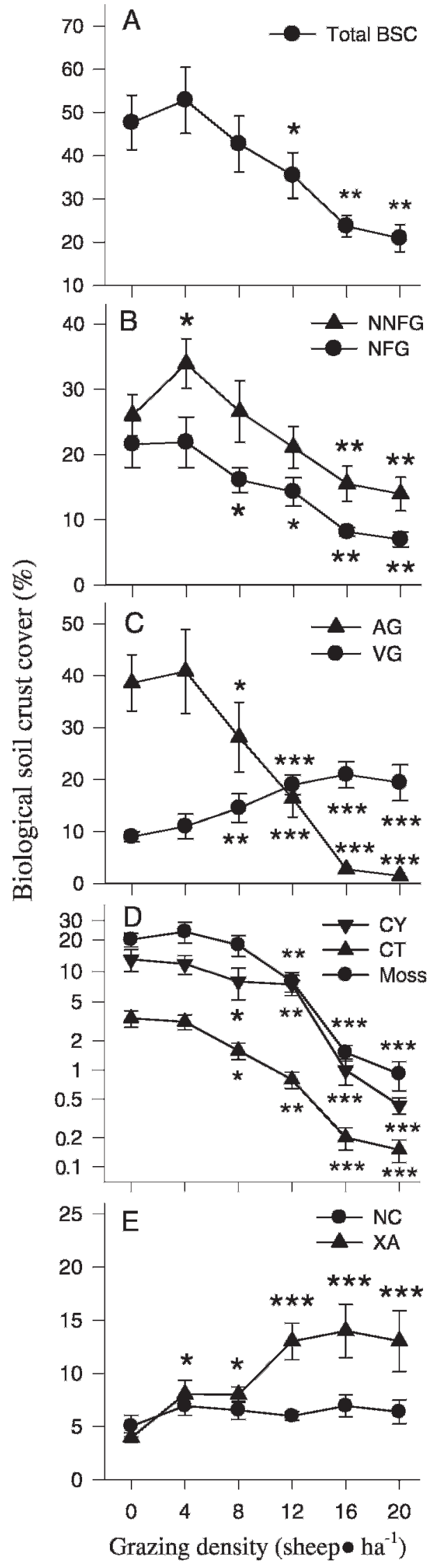

Figure 1. Grazing density effect on coverage of $\mathbf{A}$, total BSC; $\mathbf{B}$, NNFG and NFG; C, AG and VG; D, CY, CT, and moss; and E, NC and XA. Values are mean $\pm \mathrm{SD}$ for $n=3$. Asterisks above or below the error bar indicate between ethylene produced and nitrogen fixed was the theoretical 3:1 ratio.

\section{Statistical Analyses}

All samples were averaged for statistical analysis, resulting in $n=3$ independent replicates per treatment for each BSC or its components. The effects of grazing density and BSC composition and their interaction on BSC variables (coverage, $\mathrm{N}_{\mathrm{A}}$, and potential $\mathrm{N}$ input) were tested by two-way analysis of variance (ANOVA). A one-way ANOVA was employed to test differences in BSC variables among the six grazing interactions and between BSC groups and components in each grazing treatment. Multiple comparisons among pairs of means were performed using the least significant difference (LSD) test when a significant ANOVA result occurred.

\section{RESULTS}

\section{Grazing Density Effect on Total BSC Coverage}

Total BSC coverage changed little under very light and light grazing, and then decreased with increasing grazing density $\left(\mathrm{F}_{5,12}=18.2, P<0.001\right.$; Fig. $\left.1 \mathrm{~A}\right)$. With heavy and very heavy grazing, BSC coverage decreased by $50.2 \%$ and $56.1 \%$, respectively (all at $P<0.01$ ).

\section{Grazing Density Effect on Coverage of BSC Groups}

In all grazing densities but control, coverage of NNFG was significantly higher than that of NFG $\left(\mathrm{F}_{1,24}=64.0, P<0.001\right.$, Fig. 1B). With very heavy grazing, the LSD test shows that coverage of NFG and NNFG decreased by $67.7 \%$ and $46.4 \%$ of the control, respectively (all at $P<0.01$; Fig. 1B). Coverage of $A G$ and $V G$ was not different in medium grazing, but AG coverage was significantly higher than VG in lower-density grazings, and the inverse occurred in higher grazing densities $\left(\mathrm{F}_{5,24}=45.5, P<0.001\right.$; Fig. 1C).

\section{Grazing Density Effect on Coverage of BSC Components}

In control, very light, and light grazing, BSC was dominated by moss and CY, but in heavy and very heavy grazing XA and NC were dominant species $\left(\mathrm{F}_{20,60}=23.8, P<0.001\right.$; Figs. $1 \mathrm{D}$ and 1E). The results of one-way ANOVA show that moss, CY, and CT decreased in coverage with increasing grazing density $\left(\mathrm{F}_{5,12}=33.1\right.$ for moss, $\mathrm{F}_{5,12}=19.1$ for $\mathrm{CY}, \mathrm{F}_{5,12}=43.8$ for CT, all at $P<0.001$; Fig. 1D); whereas $\mathrm{XA}$ exhibited the opposite trend $\left(\mathrm{F}_{5,12}=14.2, P<0.001\right)$ and $\mathrm{NC}$ did not significantly differ among treatments $\left(\mathrm{F}_{5,12}=1.8, P>0.05\right.$; Fig. $\left.1 \mathrm{E}\right)$.

The LSD test shows that, in light grazing, coverage of CY and CT decreased by $39.1 \%$ and $53.1 \%$ as compared to the

$\leftarrow$

significant change from the control tested by LSD. Sheep were grazed rotationally three times per year for $16 \mathrm{yr}$, with $15 \mathrm{~d}$ grazing at an interval of $30 \mathrm{~d}$ from May to October. AG indicates attached group; BSC, biological soil crust; CT, Collema tenax; CY, mixed filamentous cyanobacteria; NC, Nostoc commune; NFG, nitrogen-fixer group; NNFG, non-nitrogen-fixer group; VG, vagrant group; and XA, Xanthoparmelia camtschadalis; ${ }^{\star} P<0.05 ;{ }^{\star \star} P<0.01 ;{ }^{* \star} P<0.001$. 
control, respectively (all at $P<0.05$ ). A 95\% decrease under heavy and very heavy grazing resulted in a low cover of CT and CY (all at $P<0.001$ ). Moss coverage changed little in very light and light grazing, but decreased by $92 \%$ in heavy grazing and $95 \%$ in very heavy grazing (all at $P<0.001$; Fig. 1D). Coverage of XA increased by about $100 \%$ in very light and light grazing $(P<0.05)$, and increased by more than $200 \%$ in higher grazing densities (all at $P<0.001$; Fig. 1E).

\section{Grazing Density Effect on N Fixation of BSC}

Potential $\mathrm{N}_{\mathrm{A}}$ of three $\mathrm{N}$-fixers decreased with increasing grazing density $\left(\mathrm{F}_{10,36}=88.1, P<0.001\right.$; Fig. $\left.2 \mathrm{~A}\right)$. The LSD test shows that very light grazing led to a $13.5 \%$ and $20.2 \%$ decrease in $\mathrm{N}_{\mathrm{A}}$ of $\mathrm{CY}$ and CT, respectively (all at $P<0.05$; Fig. 2A). In very heavy grazing, $\mathrm{N}_{\mathrm{A}}$ for both $\mathrm{N}$-fixers decreased to less than $0.1 \%$ of the control (all at $P<0.001$ ). In contrast, $\mathrm{N}_{\mathrm{A}}$ of $\mathrm{NC}$ was little affected by very light and light grazing, but decreased by $64.3 \%$ and $71.2 \%$ in heavy and very heavy grazing, respectively (all at $P<0.001$; Fig. 2A).

Potential $\mathrm{N}_{\mathrm{A}}$ differed among N-fixers $\left(\mathrm{F}_{2,36}=322.8\right.$, $P<0.001)$. The LSD test shows when livestock are absent or grazing density is low (very light and light grazing); the highest $\mathrm{N}_{\mathrm{A}}$ was for CT, which is about three times higher than that for $\mathrm{NC}$ and seven times higher than that for $\mathrm{CY}$ (all at $P<0.05$; Fig. 2A). However, in medium and higher grazings, $\mathrm{N}_{\mathrm{A}}$ for $\mathrm{NC}$ was higher than CT and CY (all at $P<0.001$; Fig. 2A).

\section{Grazing Density Effect on Potential N Input of BSC}

Potential $\mathrm{N}$ input of total BSC decreased with increasing grazing density $\left(\mathrm{F}_{5,36}=263.3, P<0.001\right)$. The LSD test shows that BSC N input potential decreased by $13.3 \%(P<0.05)$ in very light grazing, and decreased by $91.4 \%$ in very heavy grazing $(P<0.001$; Fig. 2B).

Both CY and CT substantially decreased in potential N input with increasing grazing density. Heavy and very heavy grazing decreased potential $\mathrm{N}$ input of $\mathrm{CT}$ and $\mathrm{CY}$ to less than $0.1 \%$ (all at $P<0.001$; Fig. 2C). In contrast, potential $\mathrm{N}$ input of $\mathrm{NC}$ changed little under very light, light, and medium grazing, but decreased by about $50-60 \%$ under heavy and very heavy grazing when compared to the control $(P<0.001$; Fig. $2 \mathrm{C})$.

\section{DISCUSSION}

All treatment sites have been subjected to grazing for $16 \mathrm{yr}$, and had only $1 \mathrm{yr}$ recovery. The postdisturbance recovery rate of BSC was very slow. For example, recovery rate for lichen cover in southern Utah is estimated at a minimum of $45 \mathrm{yr}$, whereas recovery of moss cover is estimated at $250 \mathrm{yr}$ (Belnap 1993). On the Mohave Desert, a 58 -yr recovery of BSC yielded only $6 \%$ of patches in shrubless areas covered with soil lichens and mosses (Brainard 1998). Therefore, 1 yr of removal of livestock should not be sufficient for crust recovery, and BSC changes in this research mostly resulted from grazing.

\section{Grazing Effect on Coverage and Composition of BSCs}

Livestock trampling is the most common disturbance of grazing to BSCs (Warren and Eldridge 2003). BSCs are generally
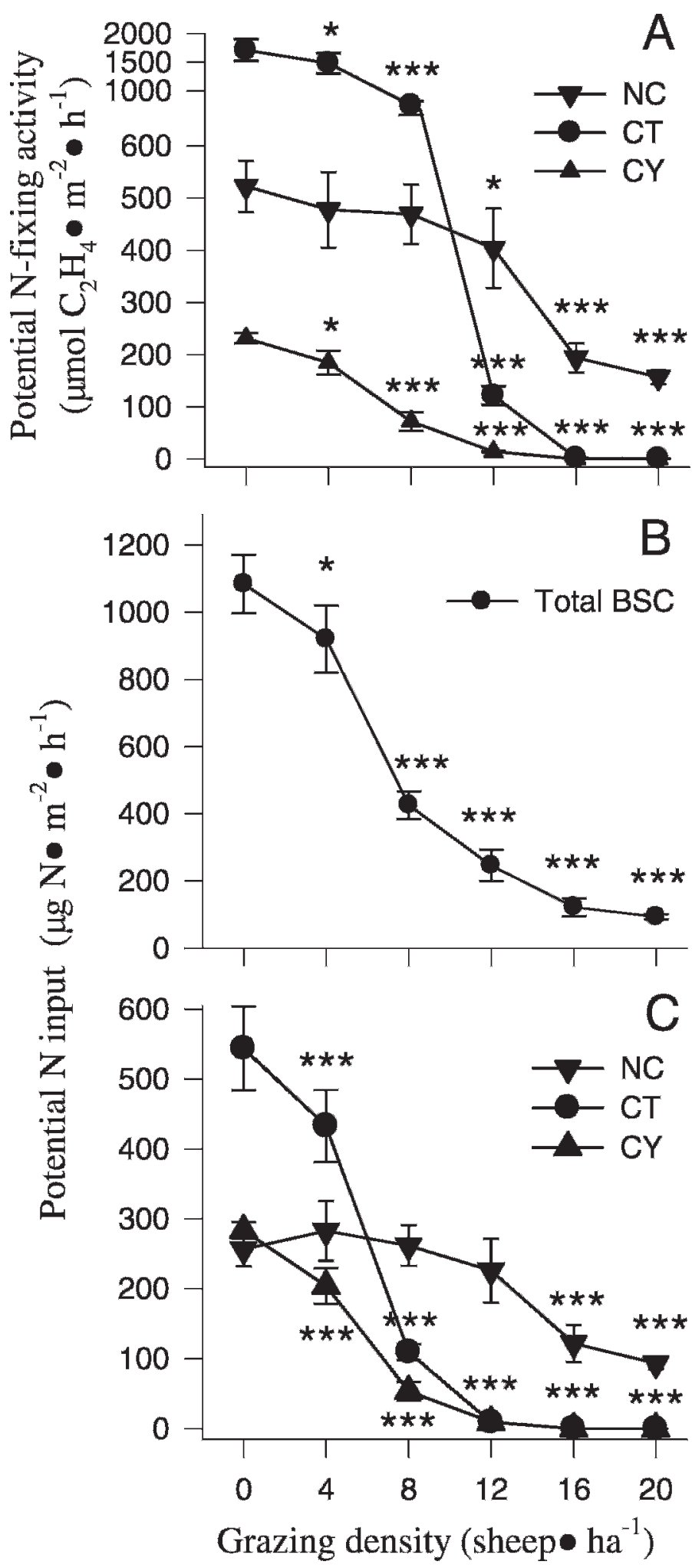

Figure 2. Grazing density effect on potential nitrogen (N)-fixing activity of $\mathbf{A}, \mathrm{CT}, \mathrm{CY}$, and $\mathrm{NC}$ and potential $\mathrm{N}$ input of $\mathbf{B}$, total BSC and $\mathbf{C}$, the three $\mathrm{N}$ fixers. Values are mean \pm SD for $n=3$. Asterisks above or below the error bar indicate significant change from the control tested by LSD. Sheep were grazed rotationally three times per year for $16 \mathrm{yr}$, with $15 \mathrm{~d}$ grazing at an interval of $30 \mathrm{~d}$ from May to October. BSC indicates biological soil crust; $\mathrm{CT}$, Collema tenax, $\mathrm{CY}$, mixed filamentous cyanobacteria; N, nitrogen; and NC, Nostoc commune; ${ }^{\star} P<0.05 ;{ }^{*} P<0.01$; ${ }^{* *} P<0.001$. 
thought to be susceptible to this mechanical disturbance, which can cause marked changes in cover and species composition of BSCs (Eldridge and Greene 1994; Yates et al. 2000; Thomas and Dougill 2006). Our findings in the Inner Mongolia grassland show that long-term grazing can lead to a reduction in BSC coverage, as indicated by the negative effect of grazing density on total BSC coverage (Fig. 1A). Very light and light grazing had no significant effect on BSC coverage, whereas heavy and very heavy grazing can lead to a more than $50 \%$ decrease in BSC coverage (Fig. 1A), indicating that the degree of grazing damage to BSC is related to grazing level. This coincides with other studies suggesting that light grazing had little effect on BSC cover (Anderson 1994), but that heavy grazing resulted in a substantial decrease or total destruction of BSCs (Memmott et al. 1998; Warren and Eldridge 2003).

Our results indicate that grazing density can affect composition of BSCs. Increasing grazing level led to greater abundance of NNFG compared with NFG, and a general decline in their coverage (Fig. 1B). In contrast, AG and VG showed opposite trends of change in coverage with increasing grazing density (Fig. 1C). Moss and CY that dominated BSC community in the control, very light, and light grazing decreased in coverage with increasing grazing density, whereas XA coverage showed an opposite trend, and dominated BSC community in heavy and very heavy grazing (Figs. 1D and 1E). Taken together, these results indicate that increasing grazing density can shift BSCs from a high-cover, AG-dominated community to a low-cover, VG- and NNFG-dominated community (Figs. 1A-1C).

Grazing Effect on the Importance of BSCs in Soil Stabilization BSCs can stabilize soil against both water and wind erosion (Malam Issa et al. 2001; Langston and McKenna Neuman 2005; Barger et al. 2006). The general decline trends in BSC and AG coverage (Figs. $1 \mathrm{~A}$ and $1 \mathrm{C}$ ) show that increasing grazing density can substantially decrease surface soil stability by its effects on coverage and composition of BSCs. Greater cover of BSC is often associated with more stable soil surface, and lichens and bryophytes are also associated with improved soil stability (Eldridge and Koen 1998). Welldeveloped BSCs with full moss and lichen development and high cyanobacterial biomass had greater friction threshold velocities (and hence higher capability of soil stabilization) than the poorly developed BSC with no moss and lichen (Belnap and Gillette 1997). In our study, a shift of a high cover of AG-dominated BSC community to a low cover of VG-dominated community, and a decrease in coverage of moss, CY, and CT, imply a negative effect of grazing on soil stability (Figs. 1A-1D). This has been supported by other studies that attributed the severely increased susceptibility of soil to wind and water erosion to the decline of BSC caused by livestock grazing (Gillette and Dobrowolski 1993; Eldridge 1998; Leys and Eldridge 1998).

Grazing and N-Fixers' Effect on $\mathrm{N}_{\mathrm{A}}$ and Potential N Input of BSC Our results indicate that grazing and species composition were crucial for $\mathrm{N}$ fixation and $\mathrm{N}$ input of BSC. In general, $\mathrm{N}_{\mathrm{A}}$ and potential $\mathrm{N}$ input of the three $\mathrm{N}$-fixers decreased with increasing grazing density, indicating that grazing disturbance can negatively affect $\mathrm{BSC} \mathrm{N}$ fixation and $\mathrm{N}$ input (Figs. 2A-2C). The negative effect of grazing on BSC N fixation has been reported in studies at other locations that found mechanical disturbance, including livestock trampling, can decrease BSC N-fixing rate (Belnap et al. 1994; Belnap 1996). The decrease in total BSC potential $\mathrm{N}$ input can be largely due to the negative effects of grazing on coverage of NFG (Fig. 1B), CT, and CY (Fig. 1D), and on $\mathrm{N}_{\mathrm{A}}$ of the three $\mathrm{N}$-fixers (Fig. 2A). This is supported by substantial evidence suggesting that grazing has a negative effect on BSC $\mathrm{N}$ input through altering cover and $\mathrm{N}$-fixing rate of BSC. For example, Floyd et al. (2003) found that grazing can lead to a reduction in cover of $\mathrm{N}$-fixing crusts. Jeffries et al. (1992) reported that grazing can result in an $85-95 \%$ decrease in BSC $\mathrm{N}$ fixation in grazed areas, whereas Klopatek (1992) suggested that $\mathrm{N}$ input can be reduced by as much as two orders of magnitude.

The significant differences in $\mathrm{N}_{\mathrm{A}}$ and potential $\mathrm{N}$ input among three $\mathrm{N}$-fixers indicate that BSC $\mathrm{N}$ fixation and input can be affected by changes in BSC species composition (Belnap 2002). NC appears to be more tolerant to grazing than CT and $\mathrm{CY}$, because NC coverage was little affected by grazing (Fig. 1E), and its $\mathrm{N}_{\mathrm{A}}$ (Fig. 2A) and potential $\mathrm{N}$ input (Fig. 2C) were relatively insensitive to grazing levels. In heavy and very heavy grazing, $\mathrm{N}_{\mathrm{A}}$ and potential $\mathrm{N}$ input of $\mathrm{CT}$ and $\mathrm{CY}$ decreased to less than $0.1 \%$ of the control; whereas $\mathrm{N}_{\mathrm{A}}$ of $\mathrm{NC}$ decreased to $30-35 \%$, and its potential $\mathrm{N}$ input decreased by $40-50 \%$ of the control and accounted for more than $99 \% \mathrm{~N}$ input by BSCs (Figs. 2A and 2C). Therefore, the substantial reduction in $\mathrm{N}_{\mathrm{A}}$ and potential $\mathrm{N}$ input of $\mathrm{BSC}$ might be expected from decrease in $\mathrm{N}_{\mathrm{A}}$ and coverage of both CT and CY.

Our results show that even very light grazing can lead to a $13.3 \%$ reduction in total BSC N input potential (Fig. 2B) due to the decreased $\mathrm{N}_{\mathrm{A}}$ of both CT and CY (Fig. 2A). In heavy and very heavy grazing densities, potential $\mathrm{N}$ input of BSC decreased by one order of magnitude (Fig. 2B), owing to the further decreased coverage of both CY and CT (Fig. 1D) and the substantially decreased $\mathrm{N}_{\mathrm{A}}$ of the three $\mathrm{N}$-fixers (Fig. 2A). Because recovery rates of soil crusts are slow (Eldridge and Greene 1994; Brainard 1998), this reduction can be a long-term phenomenon. For instance, in an area released from grazing for $25 \mathrm{yr}, \mathrm{N}$ fixation was still 2.5 times less than in an adjacent, never-grazed area due to a reduction in Collema cover (Evans and Belnap 1999). $\mathrm{N}$ is the primarily limiting factor influencing net primary productivity in many terrestrial ecosystems (Vitousek and Howarth 1991), and N fixation by BSC can be a dominant source of $\mathrm{N}$ input into many ecosystems (Evans and Ehleringer 1993; Evans and Johansen 1999). The long-term decline of importance of BSC in $\mathrm{N}$ input and soil stabilization by grazing can have important impacts on ecosystem $\mathrm{N}$ cycling and soil $\mathrm{N}$ availability in Inner Mongolia grasslands.

\section{MANAGEMENT IMPLICATIONS}

The effects of grazing on BSC coverage, composition, and functions in soil stabilization and ecosystem $\mathrm{N}$ input are highly 
related to grazing density. In the Inner Mongolia grasslands under study, very light grazing seems to have little impact on relative importance of BSC in soil stabilization, but resulted in a $13.3 \%$ decrease in BSC N input potential. The higher grazing densities led to further reductions in importance of BSC in $\mathrm{N}$ input and soil stabilization. Heavy and very heavy grazing caused a decrease in potential $\mathrm{N}$ input by one order of magnitude, and a reduction in relative importance of BSC in soil stabilization via a shift from a high coverage of an AG (mainly moss, CY, and CT)dominated BSC community to a low coverage of a VG- and NNFG (mainly XA)-dominated community. Given low recovery rates of BSCs, it might be expected that the long-term decline in the importance of BSC in soil stabilization and $\mathrm{N}$ input caused by overgrazing may result in decreases in soil stability and soil $\mathrm{N}$ availability. Such decreases may lead to a further decline in grassland productivity. Therefore, constraining grazing level to a very light grazing density, and to a lesser extent, a light grazing density, are likely preferred practices for conserving BSC and its functions in N fixation and soil stabilization, thus benefiting the conservation and ecologically sustainable use of Inner Mongolia grasslands.

\section{ACKNOWLEDGMENTS}

We thank Professors Oberster J. Sun and Ben X. Wu, and two anonymous reviewers for their helpful comments and constructive suggestions.

\section{LITERATURE CITED}

Anderson, J. L. 1994. Exclosures on the Beaver Dam slope in Arizona and Utah. Rangelands 16:184-188.

Barger, N. N., J. E. Herrick, J. Van Zee, and J. Belnap. 2006. Impacts of biological soil crust disturbance and composition on $\mathrm{C}$ and $\mathrm{N}$ loss from water erosion. Biogeochemistry 77:247-263.

BeLnAP, J. 1993. Recovery rate of cryptobiotic crusts: inoculant use and assessment methods. Great Basin Naturalist 53:89-95.

BELNAP, J. 1996. Soil surface disturbance in cold deserts: effects on nitrogenase activity in cyanobacterial-lichen soil crusts. Biology and Fertility of Soils 23:362-367.

BeLNAP, J. 2002. Nitrogen fixation in biological soil crusts from southeast Utah, USA. Biology and Fertility of Soils 35:128-135.

BELNAP, J. 2003. Factors influencing nitrogen fixation and nitrogen release in biological soil crusts. In: J. Belnap and 0. L. Lange [EDs.]. Biological soil crusts: structure, function, and management. Berlin, Germany: Springer. p. 3-30.

Belnap, J., and D. A. Gillette. 1997. Disturbance of biological soil crusts: impacts on potential wind erodibility of sandy desert soils in southeastern Utah. Land Degradation and Development 8:355-362.

BelnAP, J., And D. A. Gillette. 1998. Vulnerability of desert biological soil crusts to wind erosion: the influences of crust development, soil texture, and disturbance. Journal of Arid Environments 39:133-142.

Belnap, J., K. T. Harper, and S. D. WarRen. 1994. Surface disturbance of cryptobiotic soil crusts: nitrogenase activity, chlorophyll content and chlorophyll degradation. Arid Soil Research and Rehabilitation 8:1-8.

BrainaRd, J. 1998. Patton tank marks suggest long recovery. Science News 154:87.

ELDRIDGE, D. J. 1998. Trampling of microphytic crusts on calcareous soils, and its impact on erosion under rain-impacted flow. Catena 33:221-239.
Eldridge, D. J., And R. S. B. Greene. 1994. Microbiotic soil crusts: a review of their roles in soil and ecological processes in the rangelands of Australia. Australian Journal of Soil Research 32:389-415.

EldRIDGE, D. J., AND T. B. KoEn. 1998. Cover and floristics of microphytic soil crusts in relation to indices of landscape health. Plant Ecology 137:101-114.

Evans, R. D., and J. Belnap. 1999. Long-term consequences of disturbance on nitrogen dynamics in an arid ecosystem. Ecology 80:150-160.

Evans, R. D., AND J. R. Ehleringer. 1993. A break in the nitrogen cycle in aridlands? Evidence from $\delta^{15} \mathrm{~N}$ of soils. Oecologia $94: 314-317$.

Evans, R. D., and J. R. Johansen. 1999. Microbiotic crusts and ecosystem processes. Critical Review in Plant Sciences 18:183-225.

Floyd, M. L., T. L. Fleischner, D. Hanna, and P. Whitefield. 2003. Effects of historic livestock grazing on vegetation at Chaco Culture National Historic Park, New Mexico. Conservation Biology 17:1703-1711.

Gillette, D. A., And J. P. Dobrowolskı. 1993. Soil crust formation by dust deposition at Shaartuz, Tadzhik, S.S.R. Atmospheric Environment 27A:2519-2525.

Hardy, R. W. F., R. D. Burns, and R. D. Holsten. 1973. Applications of the acetylene-ethylene assay for measurement of nitrogen fixation. Soil Biology \& Biochemistry 5:59-72.

Harper, K. T., AND J. Belnap. 2001. The influence of biological soil crusts on mineral uptake by associated vascular plants. Journal of Arid Environments 47:347-357.

HAWKES, C. V. 2004. Effects of biological soil crust on germination of four endangered herbs in a xeric Florida shrubland during drought. Plant Ecology 170:121-134.

Jefreies, D. L., J. M. Klopatek, S. O. Link, and H. Bolton, Jr. 1992. Acetylene reduction by cryptogamic crusts from a blackbrush community as related to resaturation and dehydration. Soil Biology \& Biochemistry 24:1101-1105.

KLopateK, J. M. 1992. Cryptogamic crusts as potential indicators of disturbances in semi-arid landscapes. In: D. H. McKenzie, D. E. Hyatt, and V. J. McDonald [EDS.]. Ecological indicators. London, United Kingdom: Elsevier Applied Science. p. 773-786.

Langston, G., and C. Mckenna Neuman. 2005. An experimental study on the susceptibility of crusted surfaces to wind erosion: a comparison of the strength properties of biotic and salt crusts. Geomorphology 72:40-53.

LEYS, J. F., AND D. J. ElDRIDGE. 1998. Influence of cryptogamic crust disturbance to wind erosion on sand and loam rangeland soils. Earth Surface Processes and Landforms 23:963-974.

Li, S. G., Y. Harazono, T. Olkawa, H. L. Zhao, Z. Y. He, and X. L. Chang. 2000. Grassland desertification by grazing and the resulting micrometeorological changes in Inner Mongolia. Agricultural and Forest Meteorology 102:125-137.

LI, X. Z., X. R. XING, And Z. Z. CHen. 2001. Effect of grazing rate on biomass and element composition of Xanthoparmelia camtschadalis. Chinese Journal of Applied Ecology 12:369-373. [In Chinese with English abstract.]

López-Hernández, D., S. Santaella, and P. Chacón. 2006. Contribution of nitrogenfixing organisms to the N budget in Trachypogon savannas. European Journal of Soil Biology 42:43-50.

Malam Issa, 0., Y. Le Bissonnais, C. Défarge, and J. Trichet. 2001. Role of cyanobacterial cover on structural stability of sandy soils in the Sahelian part of western Niger. Geoderma 101:15-30.

Memmott, K. L., V. J. Anderson, and S. B. Monsen. 1998. Seasonal grazing impact on cryptogamic crusts in a cold desert ecosystem. Journal of Range Management 51:547-550.

Pendleton, R. L., B. K. Pendleton, G. L. Howard, and S. D. Warren. 2003. Growth and nutrition content of herbaceous seedlings associated with biological soil crusts. Arid Land Research and Management 17:271-281.

Rivera-Agullar, V., H. Godínez-Alvarez, I. Manuell-Cacheux, and S. RodríguezZaragoza. 2005. Physical effects of biological soil crusts on seed germination of two desert plants under laboratory conditions. Journal of Arid Environments 63:344-352.

Thomas, A. D., And A. J. Dougill. 2006. Distribution and characteristics of cyanobacterial soil crusts in the Molopo Basin, South Africa. Journal of Arid Environments 64:270-283.

Vitousek, P. M., AND L. R. HowarTh. 1991. Nitrogen limitation on land and in the sea: how can it occur? Biogeochemistry 13:87-115. 
Wang, S. P., Y. H. LI, Y. F. Wang, and Z. Z. Chen. 2001. Influence of different stocking rates on plant diversity of Artemisia frigida community in Inner Mongolia Steppe. Acta Botanica Sinica 43:89-96.

Warren, S. D., AND D. J. Eldridge. 2003. Biological soil crust and livestock in arid ecosystems: are they compatible? In: J. Belnap and 0. L. Lange [EDs.]. Biological soil crusts: structure, function, and management. Berlin, Germany: Springer. p. 349-360.
WeSt, N. E. 1990. Structure and function of microphytic soil crusts in wildland ecosystems of arid and semi-arid regions. Advances in Ecological Research 20:179-223.

Yates, C. J., D. A. Norton, and R. J. Hobbs. 2000. Grazing effects on plant cover, soil and microclimate in fragmented woodlands in south-western Australia: implications for restoration. Austral Ecology 25:36-47. 